\title{
Monitoring and Evaluating the Sedimentation Process in Mosul Dam Reservoir Using Trap Efficiency Approaches
}

\author{
Issa E. Issa ${ }^{1,2}$, Nadhir Al-Ansari' ${ }^{1}$, Sven Knutsson'1, Govand Sherwany ${ }^{3}$ \\ ${ }^{1}$ Department of Civil, Environmental and Natural Resources Engineering, Luleå University of Technology, Luleå, \\ Sweden \\ ${ }^{2}$ University of Mosul, Mosul, Iraq \\ ${ }^{3}$ Ministry of Higher Education and Scientific Research-KRG, Erbil, Iraq \\ Email: issa.elias@ltu.se, nadhir.alansari@ltu.se, sven.knutsson@ltu.se,govand.sherwani@mhe-krg.org
}

Received 11 March 2015; accepted 3 April 2015; published 8 April 2015

Copyright (C) 2015 by authors and Scientific Research Publishing Inc.

This work is licensed under the Creative Commons Attribution International License (CC BY).

http://creativecommons.org/licenses/by/4.0/

(c) (i) Open Access

\section{Abstract}

Reservoirs are usually exposed to sediment accumulation problems that will lead to reduction in their storage capacity. This problem directly affects the performance of the dams and causes shortage of their useful life. The simplest technique to estimate sediment deposition rate is using sediment rating curve with sediment trapping efficiency (TE) of the reservoir. Many empirical and semi-empirical approaches have been suggested for to determine this term depending on the annual inflow rate, reservoir characteristics and features of the catchments area. In this study six different empirical methods depending on the residence time principle (water retention time) were used. These approaches were reviewed and applied to determine TE of Mosul dam reservoir (MDR) for period 1986 to 2011. The monthly operating data for inflow, outflow and water elevations for MDR were used to determine monthly TE and long-term TE for whole period of MDR using the mentioned methods. Furthermore, the monthly inflow rate for River Tigris upstream MDR, its sediment rating curve and sediment feeding from valleys around MDR were used to estimate the amount sediment coming to the reservoir. The results provided by these methods for TE with sediment coming to MDR were used to compute the amount of sediment deposited in MDR on monthly bases during this period. The results obtained were evaluated using observed bathymetric survey data that had been collected in 2011 after 25 years of the operation of the dam. The results showed all the mentioned methods gave convergent results and they were very close to bathymetric survey results for estimating the volume of sediment deposited especially that proposed by Ward which gave $0.368 \%$ percentage error. Furthermore, the result computed using monthly TE gave good agreement if compared with that long-term TE where the percentage error was ranging between $-3.229 \%$ to $1.674 \%$ for monthly adopted data and $-4.862 \%$ to $-2.477 \%$ for 
whole period data. It is believed that this work will help others to use this procedure on other reservoirs.

Keywords

Losing Storage Capacity, Mosul Dam, Reservoir Sedimentation, Sediment Trap Efficiency

\section{Introduction}

Dams are designed to serve several aspects such as water storage for irrigation, flood control, domestic uses and recreational purposes as well as hydropower generation [1]-[3]. Generally, the total water storage of reservoirs in the world has been mentioned by various sources. One such reported forms about $5 \%$ of total runoff [4] whilst others said the global gross storage capacity till 2004 was $6000 \mathrm{~km}^{3}$ [5]-[7]. Regardless of the purpose, reservoirs formed after dam construction causes changes in flow regime (or sediment transport regime) which decrease their storage capacity [1]-[3] [8]. Reservoir sedimentation is a major problem affecting directly the performance of dams and their useful life due to the reduction in the storage capacity of their reservoirs. Thus, the global loss rate or sedimentation rate of the reservoirs is around $1 \%$ of their storage capacity due to sedimentation [4] [6]. Therefore, to ensure prudent management and operation of the dams it is necessary to estimate the quantity of sediment deposited in their reservoirs. Sediment movement and deposition is a complicated phenomenon that can be affected by multiple hydraulic and hydrological factors. The dominant factors that influence the sedimentation process are sediment properties, water and sediment incoming to the reservoir, the reservoir characteristics and the mode of operating the reservoir [1] [3] [9].

The complexity of sediment transport and the deposition of sediment in a reservoir led to develop a numerous techniques to predict sediment distribution in reservoirs. These techniques can be divided as direct and indirect methods but the last techniques can be classified into theoretical and empirical or semi-empirical approaches. The empirical relationships are most commonly used than theoretical for determining the deposition rate or the reduction in the storage capacity of the reservoir because these techniques are developed depending on the field data. In addition, the empirical methods are relatively easier and quicker to be used and they require limited data. Furthermore, the theoretical approaches or models are hard to be calibrated [1]. Therefore, many empirical and semi-empirical methods have been developed using the sedimentation survey data collected for reservoirs. The simplest technique is the one where sediment rating curve with trap efficiency (TE) of the reservoir are used to estimate the sediment deposition rate. The TE is an important term that is used to estimate the amount of sediment deposited, sedimentation rate and useful life of the dam. It is an expression or index that reflects the ability of reservoir to impound the sediment. Many empirical methods were developed to determine this term depending on the annual inflow rate, reservoir characteristics and features of the catchments area [10] [11].

In this study six different empirical methods were reviewed and applied to determine monthly TE of Mosul dam reservoir (MDR) for period 1986 to 2011. These methods depend on the residence time principle (water retention time) that are reported by; Brune [12], Dendy [13], Gill [14], Ward [15], Heinemann [16] and Jothiprakash and Garg [17] (hereafter referred to as Brune, Dendy, Gill, Ward, Heinemann and Jothiprakash and Garg, respectively]. The monthly operation data for inflow, outflow and water elevations for MDR were used to determine monthly TE using the mentioned methods. Furthermore, the monthly inflow rate for River Tigris upstream MDR, its sediment rating curve and sediment feeding from valleys around MDR were also used to estimate the amount sediment entering the reservoir. The results provided by these methods for TE with sediment entering MDR were used to compute monthly amount of sediment deposited during the studied period. In addition, to the above TE of MDR for the whole period of its operation were computed using the same technique to find out the time of dam operating. These results were compared with bathymetric survey data that were collected in 2011 after 25 year of operating Mosul dam [18]. Thus, the specific aims of this study were evaluating these methods with reference to the bathymetric survey for determining the amount of sediment deposited during this period and to monitor the sedimentation process in MDR which is the biggest and the most important strategic projects in Iraq.

This project provides water for three irrigation projects that cover an area about $2500 \mathrm{~km}^{2}$ [19]. This study can 
help decision makers and planners to put prudent planning for Iraqi water resources problems especially Iraq is recently facing serious water shortage problems due to climate changes and increasing demand [19]-[23] where, the annual reduction of the water inflow for the Tigris and Euphrates Rivers before entering Iraqi territory is $0.1335 \mathrm{~km}^{3} \cdot \mathrm{yr}^{-1}$ and $0.245 \mathrm{~km}^{3} \cdot \mathrm{yr}^{-1}$ respectively [21]. In view of the foregoing, it is very important to know which technique is most suitable to adopt for MDR in the future to determine its actual storage capacities and rate of reduction of storage capacity.

\section{Methods Used to Estimate Trap Efficiency}

TE of sediment is an expression or indicator for the ability of reservoir to impound sediment and reflects the characteristic of reservoir to trapping or collecting the sediment. It plays an important role on estimating the fraction of sediment deposited within the reservoirs, determining the useful life of the dam (reservoir active storage capacity), and assessing changes in the reservoir storage capacity with time of dam operation [10] [11]. Therefore, it is very important parameter for planners, designers and operators of dams [1] [3] [16] [17] [24]. TE of sediment is the index of the portion of the deposited sediment in reservoirs to the total inflowing sediment which is usually expressed in percentage [17] [25] [26] and can be expressed as:-

$$
\text { TE } \%=100\left[\frac{\text { Total inflow sediment }- \text { Total outflow sediment }}{\text { Total inflow sediment }}\right]
$$

The sediment TE is a function of many factors from flow conditions in the river and reservoir, sediment amount and properties, geometry of reservoir and its age, location of spillway, location and depth of outlets and operation mode of reservoir [1] [8] [27]. The complexity of sedimentation process led to the development of many approaches for determining the TE within the reservoirs. Some of them are direct while others are indirect. The former uses bathymetric survey and sedimentology data and the latter uses hydrological data and reservoir features [27] [28]. Historically, several methods for calculating TE were developed but the most commonly are the empirical methods that were developed based on survey data for some reservoirs. All these methods were established based on three principles. These are; reservoir storage capacity and catchment area relationship that were suggested by Brown [29] sedimentation index of reservoir (ratio of water retention time to the mean velocity in the reservoir) proposed by Churchill [30] and hydraulic residence time principle (or inflow storage capacity ratio) by Brune. All empirical methods had been taken in their account the capacity of reservoir, annual inflow rate, feature of catchment area and reservoir geometry [1] [27]. These methods are widely used for engineering purposes. Consequently, large numbers of empirical methods have been reported, but the most commonly are:

The method proposed by Brown [29] is the first empirical curve representing the relationship between the capacity of reservoir $(C)$ and catchment area upstream the dam $(A)$. The method is expressed by the general equation [14] as:

$$
\mathrm{TE}_{\text {Brown }}=100\left[1-\left(\frac{1}{1+K \frac{C}{A}}\right)\right]
$$

where $C$ in acre-feet, $A$ in square miles and $K$ is factor depends on retention time and particle size of sediment which varies between 0.046, 0.1 and 1 for fine, medium and coarse sediment respectively [14] [31]. This method is used for catchment area that has one dam. Churchill [30], developed a concept of sediment release efficiency and proposed a relationship for this based on sedimentation index and total load of incoming sediment (Figure 1). The curve integrates both water residence time and flow velocity to calculate a "sedimentation index" for the reservoir. The method is suitable to estimate release efficiency of sediment for reservoir continuously sluiced such as stilling basin, small reservoirs and flood controlling structures [1] [17].

The above two methods were based on the reservoir capacity, catchment area and sedimentation index principles of reservoir but the following approaches depend on the hydraulic residence time principle. Brune established an empirical relationship curve for estimating long-term trap efficiency of reservoirs based on correlation between reservoir capacity and inflow ratio $(C / I)$ that was developed using the data of 44 reservoirs in the USA (Figure 2). The method is widely adopted, easy to apply and requires small amount of data and is suitable 


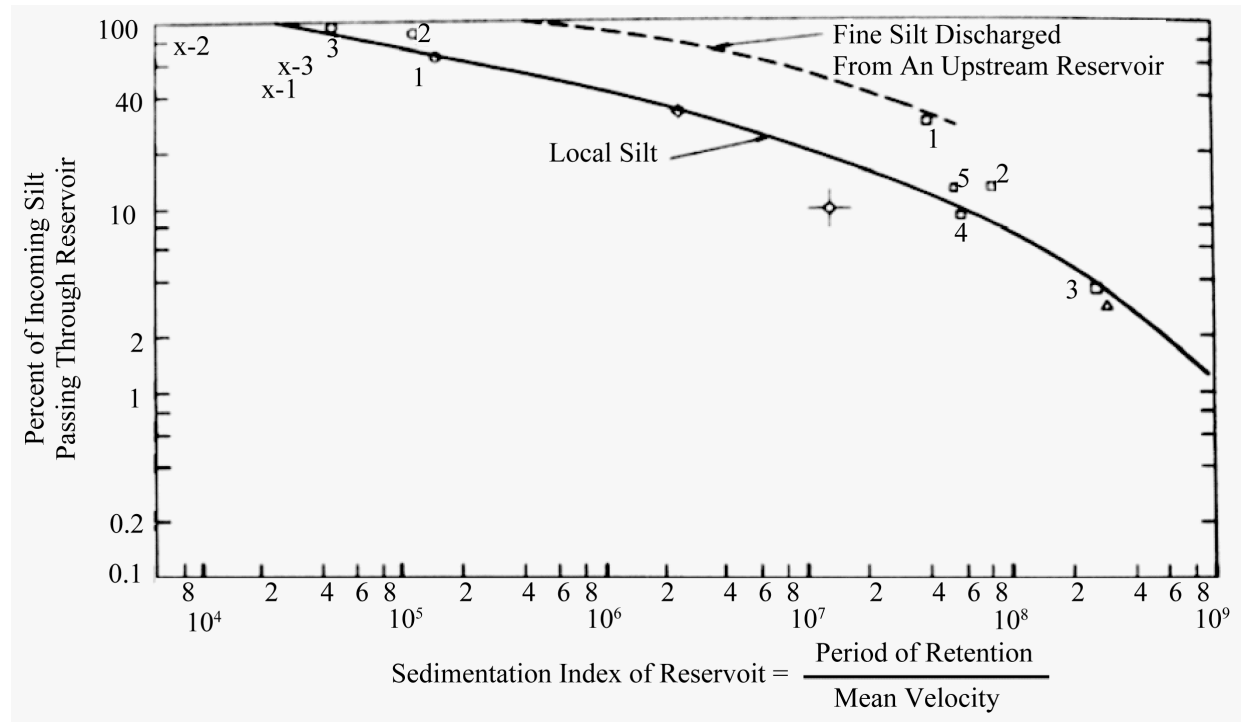

Figure 1. Churchill's [30] release efficiency curve [1].

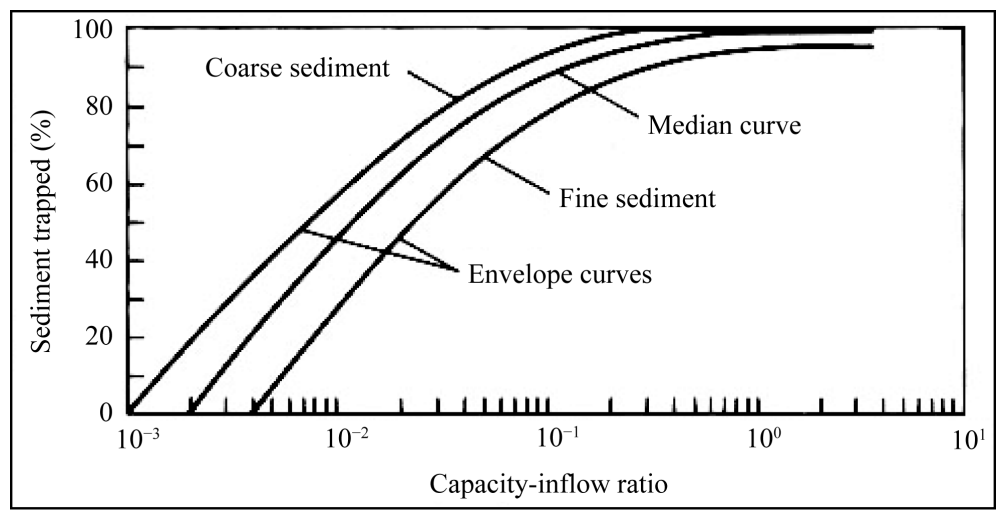

Figure 2. Brune’s curve for estimating sediment trapping [12].

for large storage capacity with normal pond reservoirs [1] [27] [31].

This relation was expressed as an empirical equation by Gill as follow:

$$
\mathrm{TE}_{\text {Brune }}=100\left[1-\frac{1}{1+50(C / I)}\right]
$$

where $C$ is in $\mathrm{m}^{3}$ and $I$ is the water inflow in $\mathrm{m}^{3} \cdot \mathrm{sec}^{-1}$. Dendy suggested algebraic equation by adding more data of 17 small reservoirs $\left(A \leq 60 \mathrm{~km}^{2}\right)$ to Brune's curve as:

$$
\mathrm{TE}_{\text {Dendy }}=100\left[0.97^{0.19^{\log (C / I)}}\right]
$$

Gill derived three equations from Brune's curves for fine (Equation (5)), medium (Equation (6)) and coarse sediment (Equation (7)):

$$
\begin{gathered}
\mathrm{TE}_{\text {Gill }}=\frac{(C / I)^{3}}{\left[1.02655(C / I)^{3}+0.02621(C / I)^{2}-133(C / I)+0.1 \times 10^{-5}\right]} \\
\mathrm{TE}_{\text {Gill }}=\frac{(C / I)}{[0.012+1.02(C / I)]}
\end{gathered}
$$




$$
\mathrm{TE}_{\text {Gill }}=\frac{(C / I)^{2}}{\left[0.994701(C / I)^{2}+0.006297(C / I)+0.3 \times 10^{-5}\right]}
$$

Ward modified Brune's equation depending on the hydraulic water residence time for largest world reservoir as:

$$
\mathrm{TE}_{\text {Ward }}=100\left[1-\frac{0.05}{(\sqrt{\Delta t})}\right]
$$

where $\Delta t$ is $(C / I)$ residence time in year, $C$ and $I$ are in hectare-m and $\mathrm{m}^{3} \cdot \mathrm{yr}^{-1}$ respectively.

Heinemann developed a new relationship for determining TE slightly difference of Brune's curve based on data of 20 ponded reservoirs in the USA (Equation (9)).

$$
\mathrm{TE}_{\text {Heinemann }}=\left[-22+\frac{119.6(C / I)}{0.012+1.02(C / I)}\right]
$$

Jothiprakash and Gargdeveloped two empirical equations to estimate TE for medium and coarse sediment depending on the related by Brune's curves for medium (Equation (10)) and coarse sediment particle (Equation (11)) as follow:

$$
\begin{gathered}
\mathrm{TE}_{\text {Jothiprakash and Garg }}=\frac{(C / I)}{[0.00013+0.01(C / I)+0.0000166 \times \sqrt{C / I}]} \\
\mathrm{TE}_{\text {Jothiprakash and Garg }}=\frac{8000-36(C / I)^{-0.78}}{\left[78.85+(C / I)^{-0.78}\right]}
\end{gathered}
$$

The mentioned equations did not take into consideration the effect of future variation or reservoir age on the TE. In this study the methods established based on the hydraulic residence time were used to evaluate and monitor monthly sedimentation processes within MDR.

\section{Site Description}

The Mosul dam is one of the most important strategic projects in Iraq. The project was constructed on the Tigris River in the north of Iraq, located $60 \mathrm{~km}$ north west of Mosul city at latitude $36^{\circ} 37^{\prime} 44^{\prime \prime} \mathrm{N}$ and longitude $42^{\circ} 49^{\prime 23 " E ~[32] ~(F i g u r e ~ 3) . ~ T h e ~ d a m ~ i s ~ a ~ m u l t i p u r p o s e ~ p r o j e c t ~ a n d ~ i t ~ s t a r t e d ~ o p e r a t i n g ~ i n ~} 1986$ to store water, flood control and hydropower generation but the main purpose was to provide water for three irrigation projects that cover $2500 \mathrm{~km}^{2}$ of agricultural area. The dam is an earth filled dam, $113 \mathrm{~m}$ high and $3650 \mathrm{~m}$ long including its spillway [32].

The MDR was constructed to impound $11.11 \mathrm{~km}^{3}$ of water at normal operation level (330 $\mathrm{m}$ a.s.l), including 8.16 and $2.95 \mathrm{~km}^{3}$ of live storage and dead storage respectively. The maximum and dead storage operation levels of its reservoir are 335 and $300 \mathrm{~m}$ a.s.l respectively. The length of reservoir is about $45 \mathrm{~km}$, with width ranging from 2 to $14 \mathrm{~km}$ at the normal level and a water surface area of $380 \mathrm{~km}^{2}$ while its shape is elongated where then River Tigris enters the upper zone and broadens close to the dam site [32] (Figure 3). The River Tigris is the main source of the water and sediment entering the reservoir. In addition, there are ten tributary valleys feed the MDR, seven from the left (northeast) side and three from the right (southwest) side [33] [34]. The catchment area above Mosul dam site is about 56,275 $\mathrm{km}^{2}$ shared by Turkey, Syria and Iraq [18] [35] [36].

\section{Available Data (Material Used)}

\subsection{Operating Data}

The water level fluctuation in MDR reservoir is small through the year. The hydropower generation and pump stations of the north Al-Jazeera project are the important structures within MDR. The power-generation facilities are located on and in the right abutment of the main dam (Figure 3). The power house is located in the toe of the 


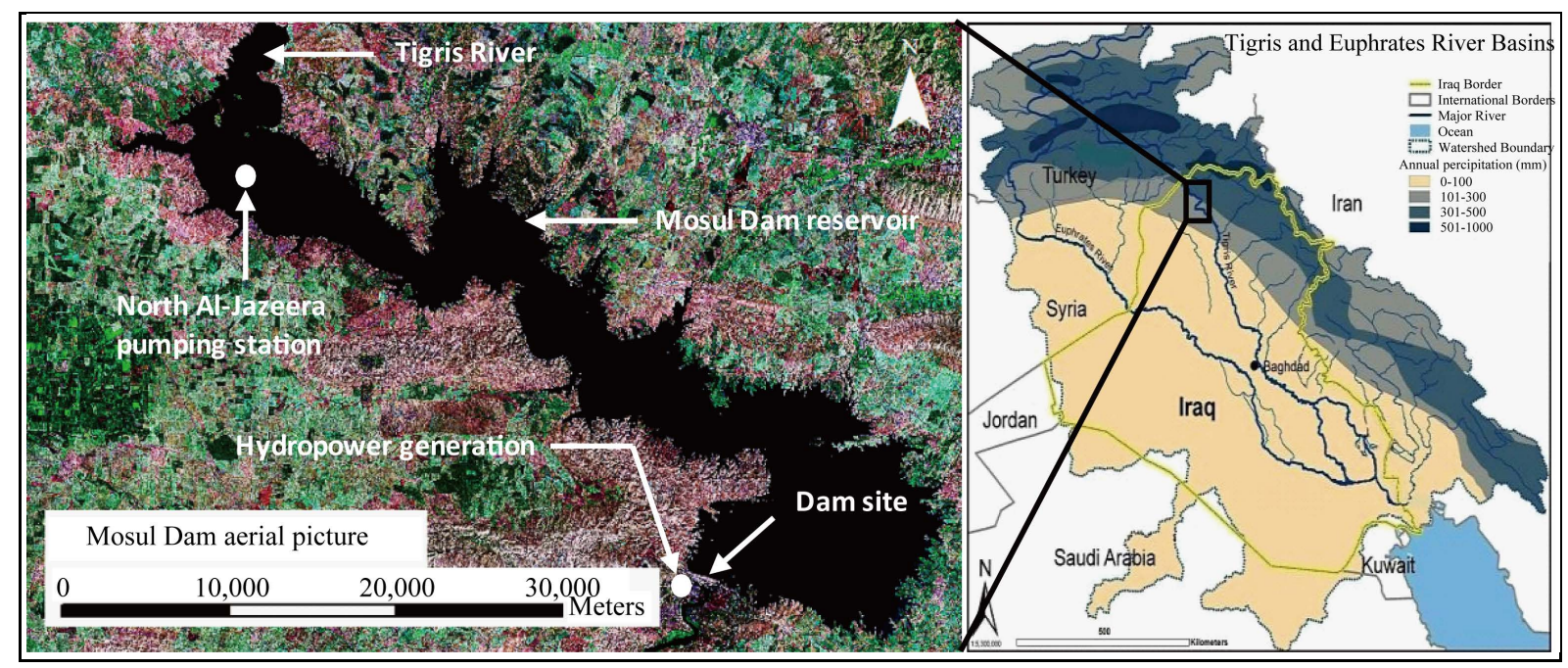

Figure 3. The location of the Mosul dam.

dam embankment and includes four turbines with total generating capacity of $750 \mathrm{MW}$. The Al-Jazeera pump station is located in the upper zone of the reservoir (latitude $36^{\circ} 49^{\prime} 20^{\prime \prime} \mathrm{N}$ and longitude $42^{\circ} 30^{\prime} 31^{\prime \prime} \mathrm{E}$ ) with a maximum water discharge $45 \mathrm{~m}^{3} \cdot \mathrm{sec}^{-1}$ (Figure 3) [32]. The long terms records of water inflow and outflow of Tigris River were provided by these stations (Figure 4). The discharges data showed that the annual inflow and outflow rates were 563 and $543 \mathrm{~m}^{3} \cdot \mathrm{sec}^{-1}$ respectively. In addition the water elevations in MDR were recorded during operation period (Figure 5).

\subsection{Sedimentation Record Data}

Tigris River is one of the two most important rivers in Iraq and is the main source of water for Mosul dam reservoir. Four major tributaries (Batman, Garzan, Botan and Al-Khabur) feed the Tigris River north of MDR from the left bank [37]. The catchment area upstream MDR is about 54,900 $\mathrm{km}^{2}$ shared by Turkey, Syria and Iraq [35] [36] while the valleys surrounding the reservoir drains an area of about $1375 \mathrm{~km}^{2}$ [18] [33]. Long term sedimentation record data were measured in the River Tigris before the construction of the dam were carried out on three gaging stations by Harza engineering company and Binnie and Partners [38]. These stations are; Mosul at dam site, Tusan and Zakho which were upstream MDR (Table 1). The sediment rating curve for Tigris River is shown in Figure 6. The sediment particle size on the river bed at this region before the construction of the dam had a median grain size diameter of $d_{50}=18 \mathrm{~mm}$ [35] [39]. In 2009, Dijla Company for Engineering Design provided a study for the same region of Tigris River. In that study, it was noted that the sediment size was $d_{50}=12.4 \mathrm{~mm}$ and the specific gravity for the bed material was $G_{\mathrm{s}}=2.65$ [40]. In addition, the annual sediment delivered by right and left valleys of MDR were $42.7 \times 10^{3}$ ton and $702 \times 10^{3}$ ton respectively [33] [41].

\subsection{Bathymetric Survey Data}

A bathymetric survey of the reservoir was conducted in 2011 after 25 years of dam operation. The survey results showed that $1.143 \mathrm{~km}^{3}$ of sediment had accumulated over the period 1986-2011. This represents an annual sediment deposition rate of $45.72 \times 10^{6} \mathrm{~m}^{3} \cdot \mathrm{yr}^{-1}$. As a result, the reservoir lost $10.29 \%$ of its storage capacity during this period [18]. The survey results were also used to construct area-storage capacity curves (Figure 3). The results indicated that the water depth below the normal operation level at the dam site was $83 \mathrm{~m}$ in 1986 . Later in 2011 it was about $80 \mathrm{~m}$ due to sedimentation. This suggests that, $3.0 \mathrm{~m}$ of sediment accumulated near the dam during the operational period of the project [18].

\section{Methodology and Techniques Used}

All the empirical methods that e mentioned above did not take into account the variation of TE with time due to changes in the factors affecting it. That means, the river behavior, the reservoir's characteristics and operation 


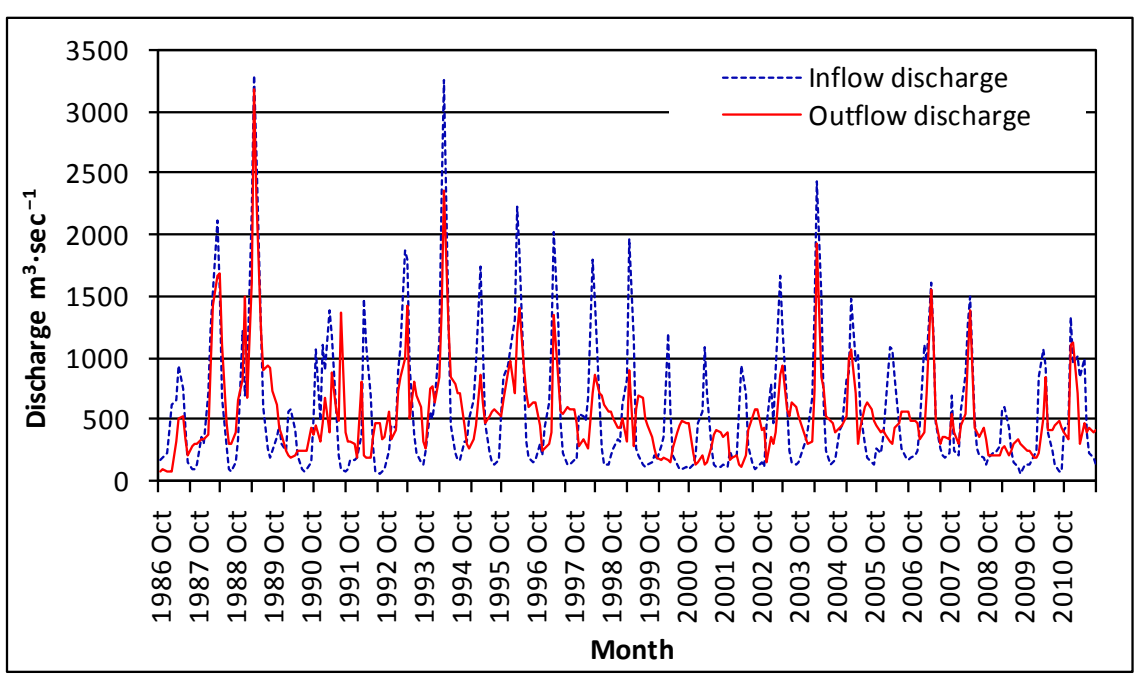

Figure 4. Average monthly inflow and outflow discharges of MDR.

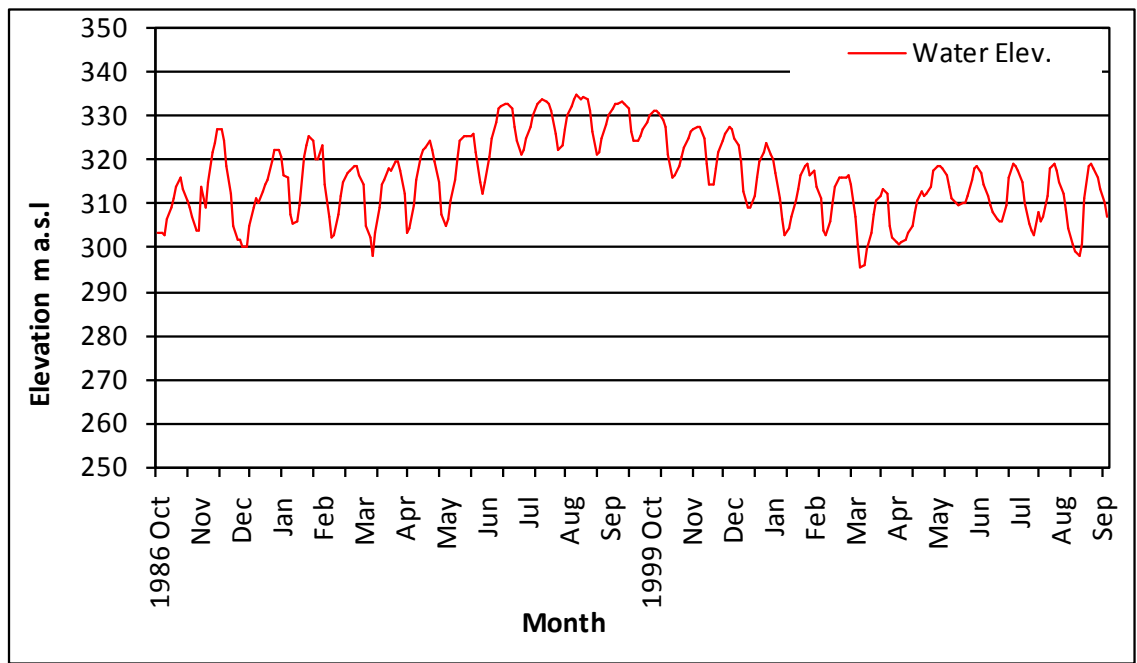

Figure 5. Average monthly water elevations of MDR.

Table 1. Locations of the gaging stations.

\begin{tabular}{ccc}
\hline Station & Easting & Northing \\
\hline Zakho & $42^{\circ} 41^{\prime} 00^{\prime \prime}$ & $37^{\circ} 08^{\prime} 00^{\prime \prime}$ \\
Tusan & $42^{\circ} 28^{\prime} 00^{\prime \prime}$ & $37^{\circ} 00^{\prime} 00^{\prime \prime}$ \\
Mosul & $42^{\circ} 49^{\prime} 03^{\prime \prime}$ & $36^{\circ} 37^{\prime} 57^{\prime \prime}$ \\
\hline
\end{tabular}

mode will remain constant in the future. Therefore, in this study, average monthly data of MDR were considered during the calculation of its TE. The calculations were performed as follow:

- Average monthly data of water elevations in MDR with stage-storage capacity curve at 1986 (Figure 7) were used to determine the average monthly storage capacity of its reservoir (Figure 8).

- The monthly data of storage capacity and inflow rate were employed to compute monthly TE of MDR by using the six previously mentioned methods that are represented by equations (3, 4, 6, 8, 9 and 10) (Figure 9).

- The inflow rate data were used with sediment rating curve for River Tigris and rate of sediment for surrounding valleys to compute average sediment entering MDR (Figure 6). 


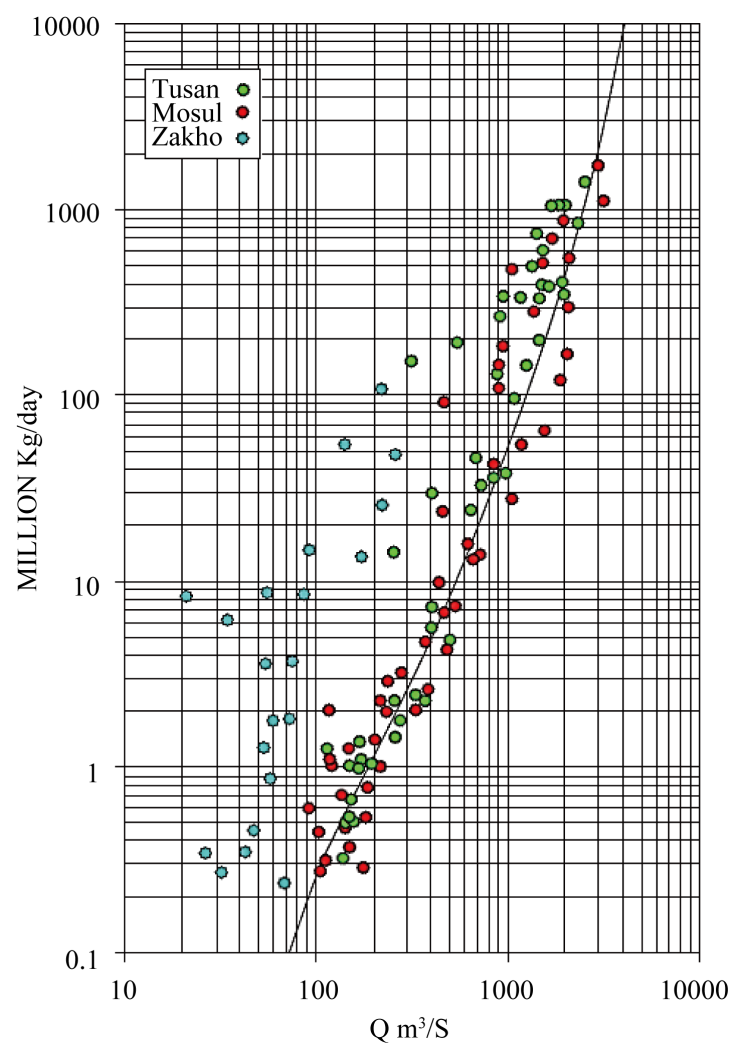

Figure 6. Sediment rating curve of Tigris River under natural condition in three gaging stations [40] (Hint: Mosul station at Mosul dam site).

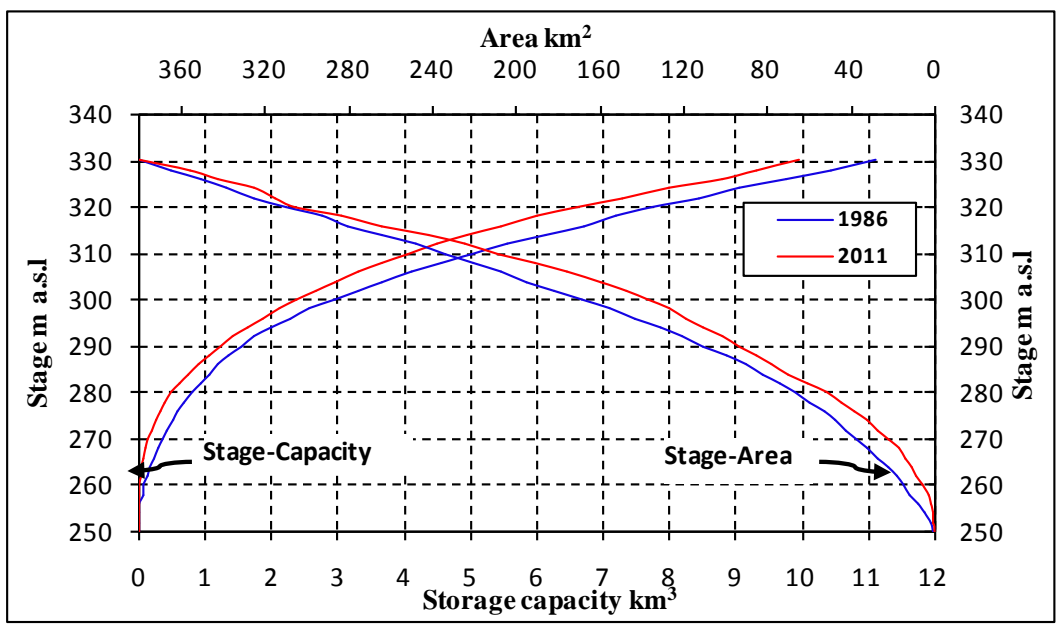

Figure 7. Area-storage capacity curves for the Mosul dam.

- The sedimentation data (Figure 10) and the monthly TE (Figure 9) were used to determine the amount of sediment deposited in the MDR.

- The deposition data were employed to correct the storage capacity of MDR after sedimentation (Figure 8). Thus the adjusted data of storage capacity were used to correct monthly TE of MDR (Figure 11).

- The corrected data of TE were used again to determine monthly sediment deposited in the MDR during its operating that will be used to compute accumulative sediment deposited in MDR during 25 year of its operating (Figure 12). 


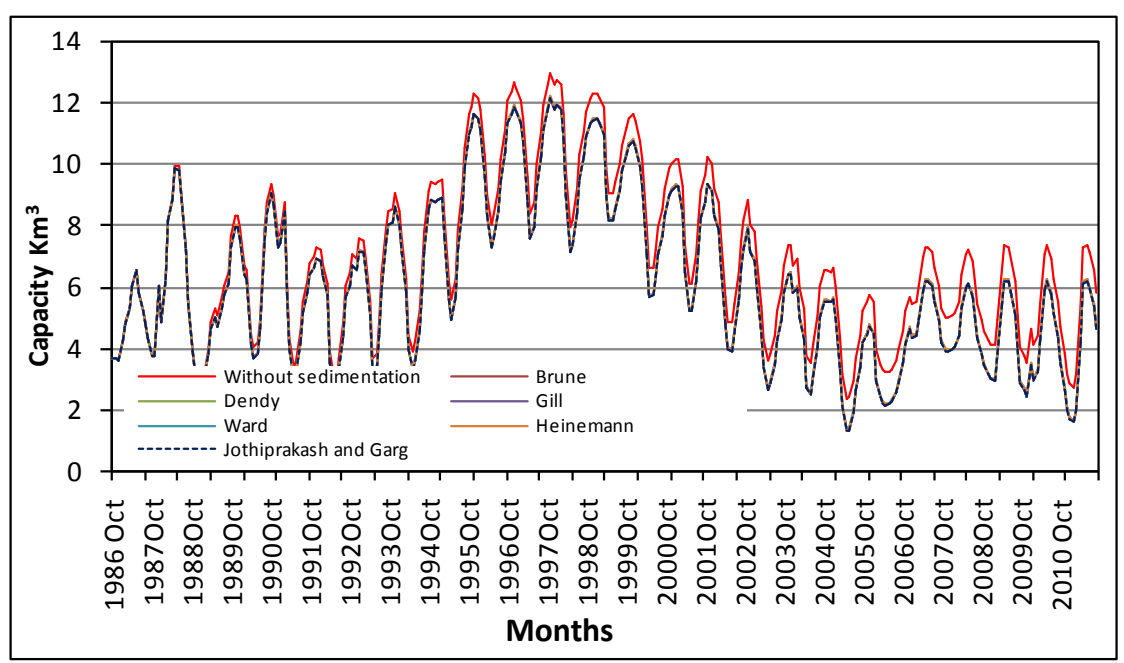

Figure 8. Monthly variation of storage capacity for MDR.

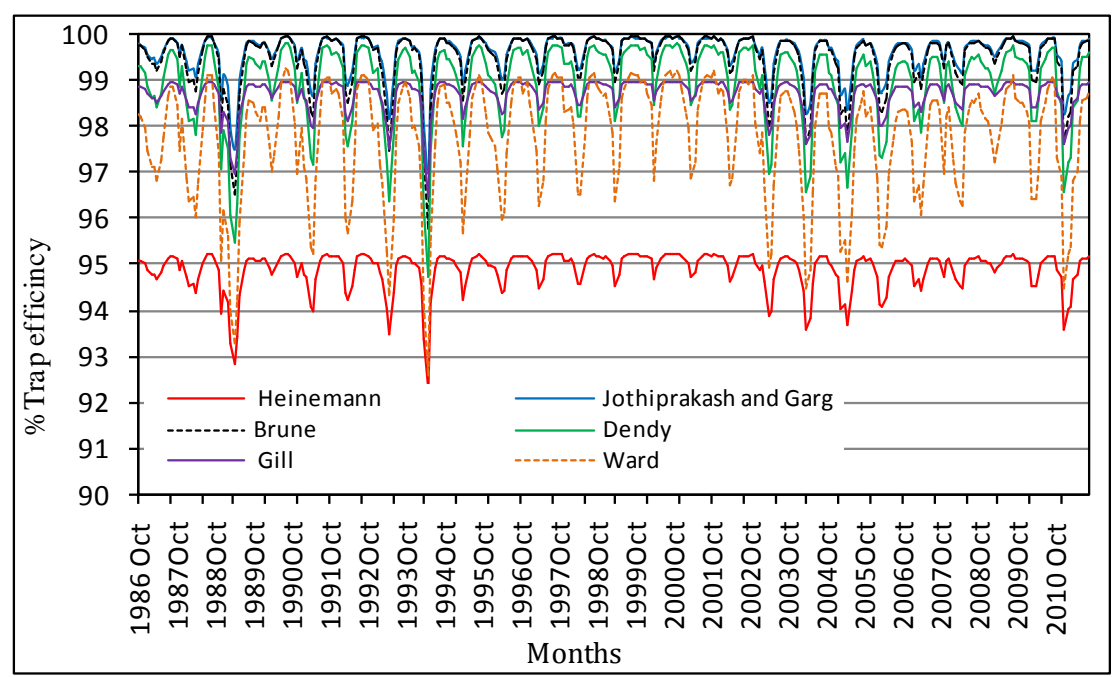

Figure 9. Average monthly TE for MDR.

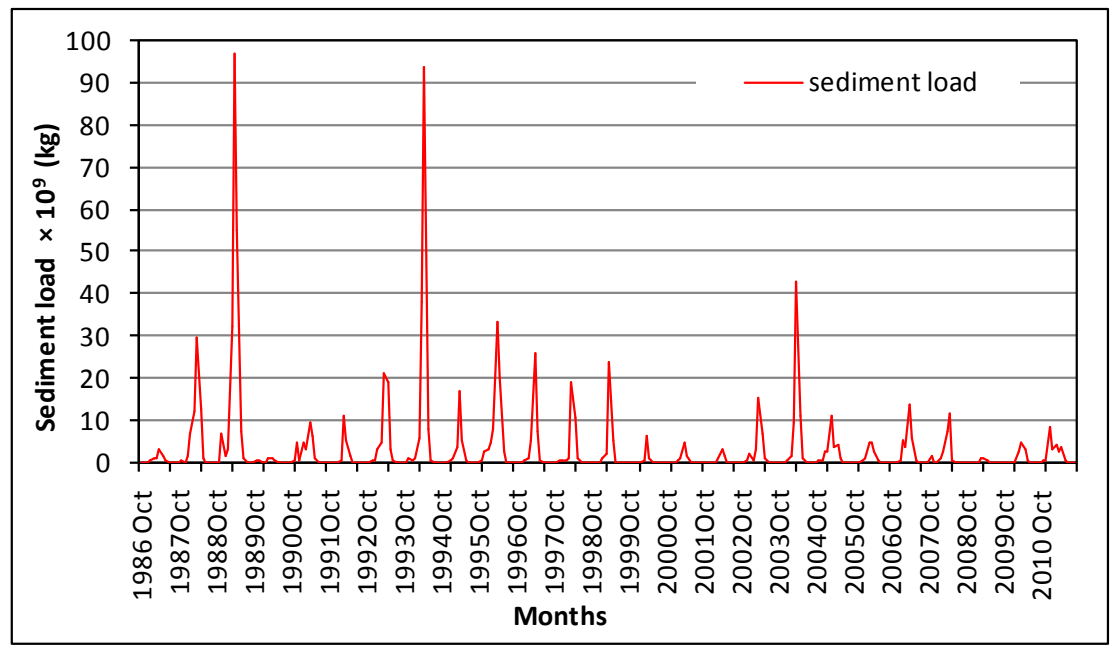

Figure 10. The monthly rate (discharge) of sediment load coming to MDR. 


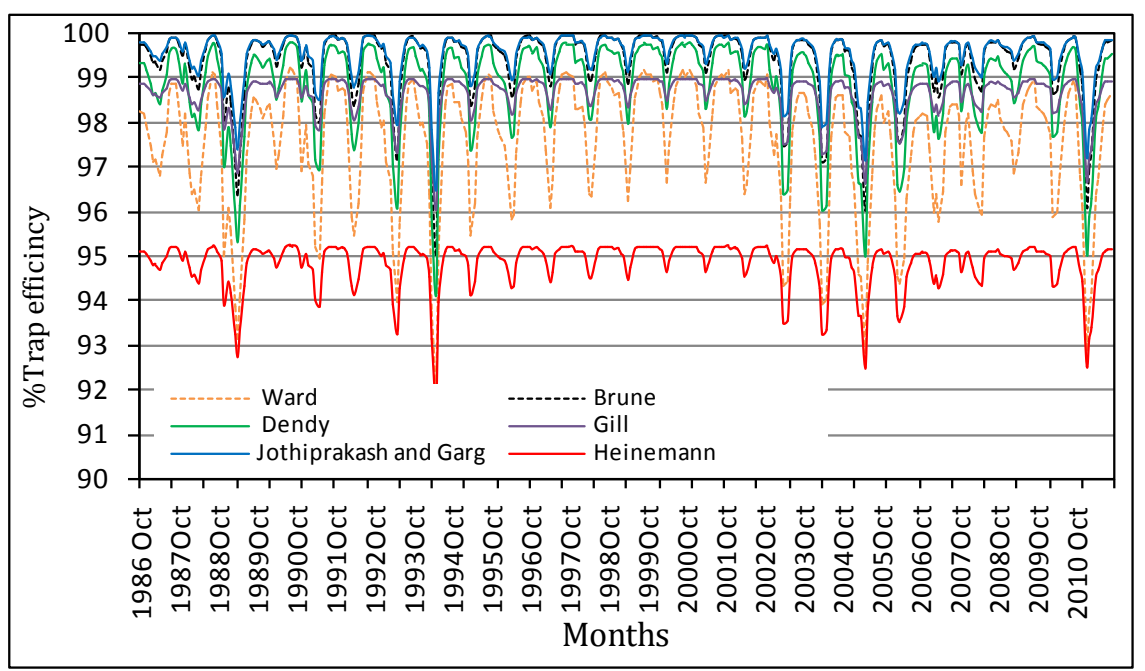

Figure 11. Adjusted TE for MDR.

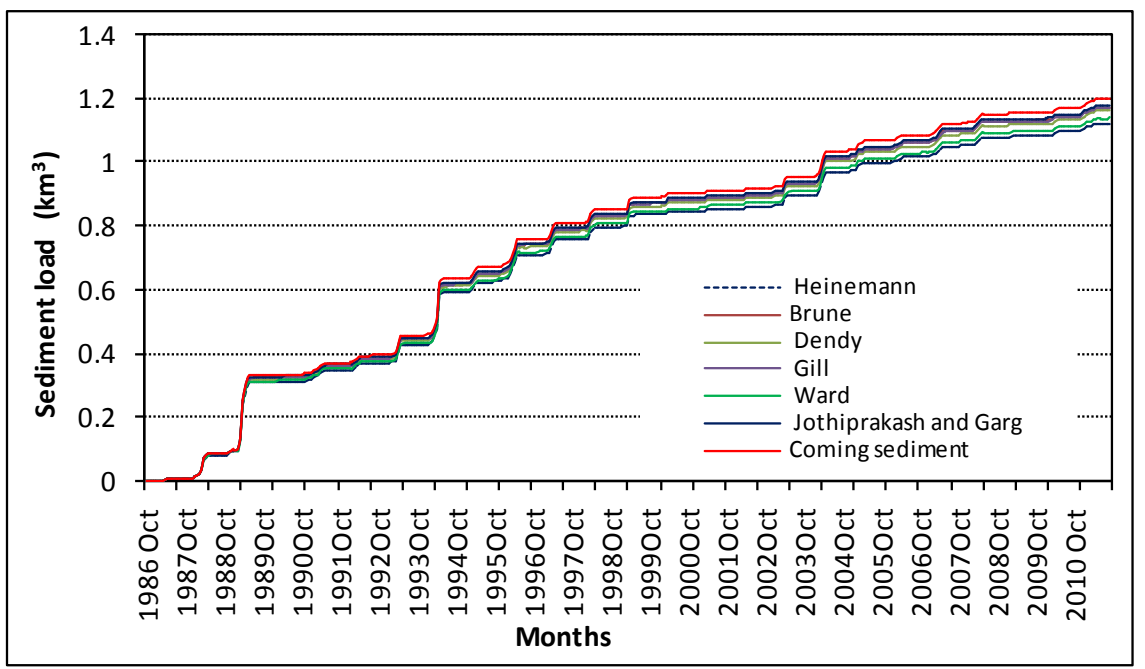

Figure 12. Accumulative sediment coming and deposited in the MDR during 25 years.

\section{Results and Discussion}

The six methods mentioned in the previous sections were evaluated by testing them against the bathymetric survey data for Mosul reservoir which were obtained by the survey conducted in 2011. The total volume of sediment deposited in the MDR was $1.143 \mathrm{~km}^{3}$ [18] and total sediment coming to the reservoir was $1.199 \mathrm{~km}^{3}$ which were computed from sediment rating of River Tigris $\left(1.17684 \mathrm{~km}^{3}\right)$ and surrounding valleys $\left(0.02216 \mathrm{~km}^{3}\right)$ (Table 2). Therefore, the real TE of MDR is $95.329 \%$. The total volume of sediment deposited in the MDR was also computed using average monthly data for inflow and storage capacity via these empirical methods (Table 2). Furthermore, to identify the effect of monthly operation on TE, the long term TE of MDR were also computed by these empirical methods depending on the average inflow and storage capacity of MDR during its operation period (25 years). The long term TEs were used to estimate the volume of sediment deposited in MDR (Table 2). The percentage errors for sediment volume deposited in MDR for all methods based on monthly average data and average of whole data (long term TE) are tabulated in Table 2. The results for all methods showed good agreement with bathymetric survey, with a percentage error ranging between $-3.237 \%$ to $1.662 \%$ for monthly adopted data and $-4.549 \%$ to $-2.450 \%$ for whole period data (Table 2). It should be mentioned however, that Ward method was giving very good result relative to the other methods with percentage error $0.350 \%$. In addition, convergent results were obtained for determining monthly storage capacity (Figure 4 ) and 
Table 2. Total sediment coming and deposited in the MDR during 25 years.

\begin{tabular}{|c|c|c|c|c|c|c|c|}
\hline \multirow[b]{2}{*}{ Methods } & \multirow{2}{*}{$\begin{array}{l}\text { Total sediment } \\
\text { coming }\left(\mathrm{km}^{3}\right)\end{array}$} & \multicolumn{3}{|c|}{ Depending the monthly TE } & \multicolumn{3}{|c|}{ Depending the long-term TE } \\
\hline & & Average TE & $\begin{array}{l}\text { Total sediment } \\
\text { deposited }\left(\mathrm{km}^{3}\right)\end{array}$ & $\%$ Error & Average TE & $\begin{array}{l}\text { Total sediment } \\
\text { deposited }\left(\mathrm{km}^{3}\right)\end{array}$ & $\%$ Error \\
\hline Brune & 1.199 & 97.818 & 1.173 & -2.625 & 99.573 & 1.194 & -4.462 \\
\hline Dendy & 1.199 & 96.880 & 1.162 & -1.662 & 99.003 & 1.187 & -3.850 \\
\hline Gill & 1.199 & 97.708 & 1.172 & -2.537 & 98.759 & 1.184 & -3.587 \\
\hline Ward & 1.199 & 94.975 & 1.139 & 0.350 & 97.686 & 1.171 & -2.450 \\
\hline Heinemann & 1.199 & 93.729 & 1.124 & 1.662 & 99.960 & 1.199 & -4.899 \\
\hline Jothiprakash and Garg & 1.199 & 98.403 & 1.180 & -3.237 & 99.646 & 1.195 & -4.549 \\
\hline
\end{tabular}

volume of sediment deposited in the MDR (Figure 8).

\section{Conclusion}

Trap efficiency (TE) is one of the most informative parameters that represent the sedimentation characteristics in reservoirs. It is that proportion of trapped or deposited to the total incoming sediment in the reservoir which is usually expressed in percentage. Six empirical methods for determining this term were reviewed and applied for MDR. These methods depend on the water retention time principle. They are: Brune, Dendy, Gill, Ward, Heinemann and Jothiprakash and Garg. The empirical methods were applied to compute TE of MDR depending on average monthly data and whole data for dam operation (25 years). The results were used to determine the volume of sediment deposited in the MDR. These results were compared with those obtained using the bathymetric survey conducted in 2011 after 25 years of dam operation. The comparison of the results showed that the method proposed by Ward [15] gave good agreement with minimum percentage error $(0.350 \%)$. The results depending on the monthly TE data produced good results relative to the long term TE for estimating the volume of sedimentation.

\section{Acknowledgements}

The research presented was supported financially by Luleå University of Technology, Sweden and by the "Swedish Hydropower Centre-SVC" established by the Swedish Energy Agency, Elforsk and SvenskaKraftnät together with Luleå University of Technology, The Royal Institute of Technology, Chalmers University of Technology and Uppsala University. This support is gratefully acknowledged.

\section{References}

[1] Morris, G.L. and Fan, J. (1998) Reservoir Sedimentation Handbook, Design and Management of Dams, Reservoirs, and Watersheds for Sustainable Use. McGraw-Hill Book Co., New York, 805 p.

[2] Jain, S.K. and Singh, V.P. (2003) Water Resources Systems Planning and Management. Elsevier Science B.V.

[3] Garde, R.J. (2006) River Morphology. New Age International Ltd., New Delhi, 502 p.

[4] Yang, X.Q. (2003) Manual on Sediment Management and Measurement. World Meteorological Organization, Operational Hydrology Report No. 47, WMO-No. 948, Secretariat of the World Meteorological Organization, Geneva.

[5] Sumi, T., Okano, M. and Takata, Y. (2004) Reservoir Sedimentation Management with Bypass Tunnels in Japan. Proceedings of 9th International Symposium on River Sedimentation, Yichang, 1036-1043.

[6] Basson, G. (2008) Reservoir Sedimentation-An Overview of Global Sedimentation Rates and Predicted Sediment Deposition. Oral Contribution to the International CHR Workshop-Expert Consultation: Erosion, Transport and Deposition of Sediments, Berne, 28-30 April 2008, 74-79.

[7] Annandale, G.W. (2013) Quenching the Thirst: Sustainable Water Supply and Climate Change. Create Space Independent Publishing Platform, North Charleston, 250 p.

[8] Garde, R.J. and Raju, K.G. (1985) Mechanics of Sediment Transportation and Alluvial Stream Problems. 2nd Edition, Wiley Eastern Limited.

[9] Annandale, G.W. (1987) Reservoir Sedimentation. Elsevier Science Publisher B.V. 
[10] Smith, S.E. (1990) A Revised Estimate of the Life Span for Lake Nasser. Environmental Geology and Water Sciences, 15, 123-129. http://dx.doi.org/10.1007/BF01705100

[11] Maneux, E., Probst, J.L., Veyssy, E. and Etcheber, H. (2001) Assessment of Dam Trapping Efficiency from Water Residence Time: Application to Fluvial Sediment Transport in the Adour, Dordogne, and Garonne River Basins (France). Water Resources Research, 37, 801-811. http://dx.doi.org/10.1029/2000WR900195

[12] Brune, G.M. (1953) Trap Efficiency of Reservoirs. Transactions, American Geophysical Union, 34, 407-418. http://dx.doi.org/10.1029/TR034i003p00407

[13] Dendy, F.E. (1974) Sediment Trap Efficiency of Small Reservoirs. Transactions of the ASAE, 17, 898-988. http://dx.doi.org/10.13031/2013.36994

[14] Gill, M.A. (1979) Sedimentation and Useful Life of Reservoirs. Journal of Hydrology, 44, 89-95. http://dx.doi.org/10.1016/0022-1694(79)90148-3

[15] Ward, P.R.B. (1980) Sediment Transport and a Reservoir Siltation Formula for Zimbawe-Rhodesia. Die Siviele Ingénier in Suid-Afrika, 9-15 (Januarie).

[16] Heinemann, H.G. (1981) A New Sediment Trap Efficiency Curve for Small Reservoirs. Water Resources Bulletin, 175, 825-830. http://dx.doi.org/10.1111/j.1752-1688.1981.tb01304.x

[17] Jothiprakash, V. and Garg, V. (2008) Re-Took to Conventional Techniques for Trapping Efficiency Estimation of a Reservoir. International Journal of Sediment Research, 23, 76-84. http://dx.doi.org/10.1016/S1001-6279(08)60007-4

[18] Issa, I.E., Al-Ansari, N. and Knutsson, S. (2013) Sedimentation and New Operational Curve for Mosul Dam, Iraq. Hydrological Sciences Journal, 58, 1456-1466. http://dx.doi.org/10.1080/02626667.2013.789138

[19] Al-Ansari, N., Issa, I.E., Sherwani, G. and Knutsson, S. (2013) Sedimentation in the Mosul Reservoir of Northern Iraq. Journal of Environmental Hydrology, 21, 1-10.

[20] Droogers, P., Immerzeel, W.W., Terink, W., Hoogeveen, J., Bierkens, M.F.P., van Beek, L.P.H. and Debele, B. (2012) Water Resources Trends in Middle East and North Africa towards 2050. Hydrology and Earth System Sciences, 16, 3101-3114. http://dx.doi.org/10.5194/hess-16-3101-2012

[21] Issa, I.E., Al-Ansari, N.A., Sherwany, G. and Knutsson, S. (2014) Expected Future of Water Resources within Tigris-Euphrates Rivers Basin, Iraq. Journal of Water Resource and Protection, 6, 421-432. http://dx.doi.org/10.4236/jwarp.2014.65042

[22] Ansari, N.A., Ali, A. and Knutsson, S. (2014) Present Conditions and Future Challenges of Water Resources Problems in Iraq. Journal of Water Resource and Protection, 6, 1066-1098. http://dx.doi.org/10.4236/jwarp.2014.612102

[23] Al-Ansari, N.A., Ali, A.A. and Knutsson, S. (2015) Iraq Water Resources Planning: Perspectives and Prognoses. Proceedings of the ICCCE 2015: XIII International Conference on Civil and Construction Engineering, Jeddah, 26-27 January, 2097-2108.

[24] Yang, C.T. (1996) Sediment Transport: Theory and Practice. McGraw-Hill, New York.

[25] Verstraeten, G. and Poesen, J. (2001) Modelling the Long-Term Sediment Trap Efficiency of Small Ponds. Hydrological Processes, 15, 2797-2819. http://dx.doi.org/10.1002/hyp.269

[26] Garg, V. and Jothiprakash, V. (2008) Trap Efficiency Estimation of a Large Reservoir. ISH Journal of Hydraulic Engineering, 14, 88-101. http://dx.doi.org/10.1080/09715010.2008.10514907

[27] Espinosa-Villegas, C.O. and Schnoor, J.L. (2009) Comparison of Long-Term Observed Sediment Trap Efficiency with Empirical Equations for Coralville Reservoir, Iowa. Journal of Environmental Engineering, 135, 518-525. http://dx.doi.org/10.1061/(ASCE)0733-9372(2009)135:7(518)

[28] Lewis, S.E., Bainbridge, Z.T., Kuhnert, P.M., Sherman, B.S., Henderson, B., Dougall, C., Cooper, M. and Brodie, J.E. (2013) Calculating Sediment Trapping Efficiencies for Reservoirs in Tropical Settings: A Case Study from the Burdekin Falls Dam, NE Australia. Water Resources Research, 49, 1017-1029. http://dx.doi.org/10.1002/wrcr.20117

[29] Brown, C.B. (1944) Discussion of Sedimentation in Reservoirs. Proceedings of the American Society of Civil Engineers, 69, 1493-1500.

[30] Churchill, M.A. (1947) Discussion of “Analysis and Use of Reservoir Sedimentation Data”. Proceedings of the Federal Inter-Agency Sedimentation Conference, Denver, 6-8 May 1947, 139-140.

[31] USACE (1989) Engineering and Design: Sedimentation Investigations of Rivers and Reservoirs. Engineering Manual 1110-2-4000, Washington DC.

[32] Iraqi Ministry of Water Resources (2012) Water Resources, Mosul Dam. http://www.mowr.gov.iq/cwaterresourceview.php?id=54

[33] Ezz-Aldeen, M., Al-Ansari, N.A. and Knutsson, S. (2012) Sediment Delivery from Right Bank Valleys to Mosul Re- 
servoir, Iraq. Journal of Ecology and Environmental Sciences, 3, 50-53.

[34] Al-Ansari, N.A. (2013) Management of Water Resources in Iraq: Perspectives and Prognoses. Journal of Engineering, 5, 667-684. http://dx.doi.org/10.4236/eng.2013.58080

[35] Swiss Consultants (1979) Mosul Dam Project-Planning Report, State Organization of Dams: Republic of Iraq. Ministry of Irrigation, Volume 1, $34 \mathrm{p}$.

[36] Saleh, D.K. (2010) Stream Gage Descriptions and Stream Flow Statistics for Sites in the Tigris River and Euphrates River Basins, Iraq. US Geological Survey, Data Series 540, 154 p. http://pubs.usgs.gov/ds/540/pdf/ds540.pdf

[37] Al-Ansari, N.A. and Knutsson, S. (2011) Toward Prudent Management of Water Resources in Iraq. Journal of Advance Science and Engineering Research, 1, 53-67.

[38] Harza Engineering Company and Binnie and Partners (1964) Hydrological Survey of Iraq: Appendix A, Hydrologic Network and Data. Vol. II, Final Report, The Government of Iraq, Ministry of Agriculture, Baghdad, 486 p.

[39] Najib, Y.E. (1980) Characteristics of Tigris River at Mosul. Master's Thesis, College of Engineering, University of Mosul, Mosul, 95 p.

[40] Ezz-Aldeen, M., Al-Ansari, N.A. and Knutsson, S. (2013) Application of Swat Model to Estimate the Sediment Load from the Left Bank of Mosul Dam. Journal of Advance Science and Engineering Research, 3, 47-61.

[41] ECB, Engineering Consulting Bureau (2010) Sedimentation Study at the Intake of North Al-Jazeera Irrigation Project. Final Report, Mosul University, College of Engineering, Contract No. 20, 112 p. 